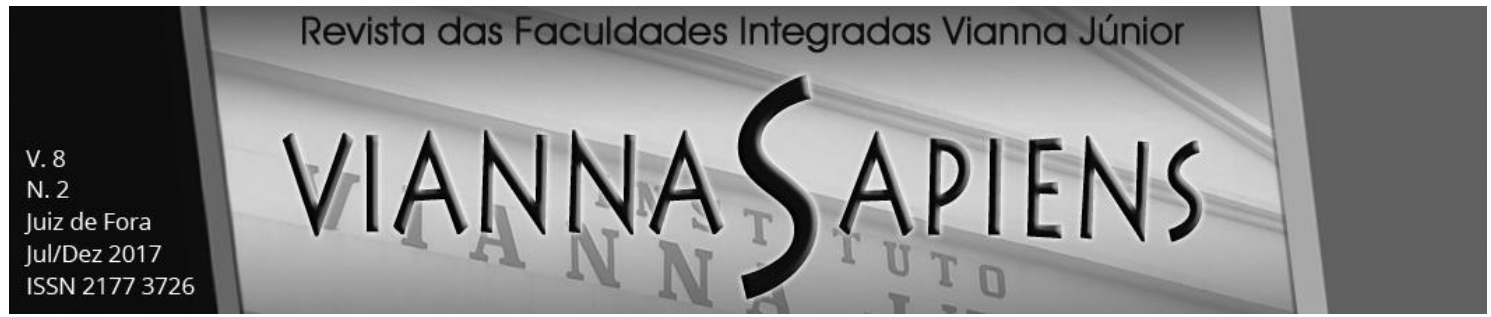

\title{
O REGISTRO DE PATENTES E CONHECIMENTO TRADICIONAL: proteção
} da biodiversidade?

Lays Gomes Martins ${ }^{1}$

\section{RESUMO}

Esse trabalho visa investigar qual é a relação entre conhecimento tradicional e a legislação que o protege, diante do interesse econômico envolvido. Objetivase uma análise acerca da legalidade e da legitimidade das patentes oriundas de componentes da biodiversidade e o discurso de sua proteção. Para desenvolver uma argumentação de modo crítico, tem-se a análise acerca do modo de viver plenamente o direito, conforme os ensinamentos de Zenon Bankowski e a estruturação da identidade moderna por Charles Taylor.Ademais, verificar-se-á fatores que anteriormente foram estabelecidos em tratados internacionais, tais como o TRIPS e a CBD, apresentando um estudo sobre a copaíba através de uma pesquisa empírica, somada à pesquisa bibliográfica e documental. Por fim, verifica-se a necessidade de reconstrução da visão sobre as comunidades tradicionais, através das linhas metodológicas delineadas.

PALAVRAS-CHAVE: BIODIVERSIDADE. CONHECIMENTO TRADICIONAL. PATENTES.

\footnotetext{
${ }^{1}$ Mestranda em Direito e Inovação pela Universidade Federal de Juiz de Fora e Graduada em Direito pela mesma instituição.Bolsista FAPEMIG, e-mail: lays gm@hotmail.com
} 


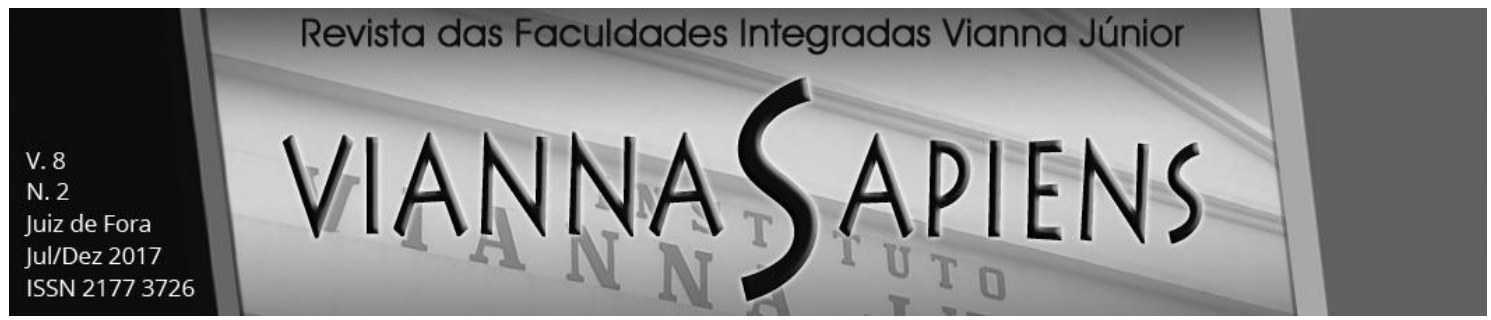

INTRODUÇÃO

Diante da riqueza presente na biodiversidade, incontáveis são os interesses econômicos que despertam ao seu redor, pois as comunidades tradicionais desenvolvem sua própria identidade através de um modo sustentável de se viver, por intermédio de seu contato direto com a natureza, suas experiências e tradições que são transmitidas a cada geração. A possibilidade de gerar lucros através do conhecimento tradicional existente, tanto em torno da fauna quanto da flora, faz com que indústrias farmacêuticas produzam cada vez mais as chamadas biopatentes, porém, grande parte delas é estruturada pelos costumes e pelas práticas dos povos tradicionais.

Esse estudo visa demonstrar que há um discurso mal estruturado em relação à "proteção do ingênuo". Daí a necessidade de uma análise do direito de propriedade intelectual e da proteção à diversidade biológica, elaborados em acordos e convenções internacionais, sendo estes o Agreementon TradeRelated Aspectsof Intellectual Property Rights (TRIPS) e a Conventionon Biological Diversity (CBD).

Em relação à base teórico-metodológica, apresentar-se-ão as discussões sobre a forma de se viver plenamente o direito, uma vez que em determinados momentos há a eminente necessidade de se romper com o que fora estabelecido por leis, mas em um âmbito harmonioso que conjuga o direito e o amor, de forma bem definida pelas alegações de Zenon Bankowski e as noções de identidade a serem formadas pelo trabalho de Taylor.

A presença dessa abordagem delineará uma série de questionamentos sobre o atual registro de patentes: quais são as melhores formas de se proteger o conhecimento tradicional? Qual é a relevância do conhecimento tradicional para que ocorra o desenvolvimento científico? Quais são os meios mais propícios para evitar a biopirataria?

Inicialmente, esse estudo apresentará os referenciais teóricos com uma estrutura metodológica que proporcionará um olhar crítico acerca da 


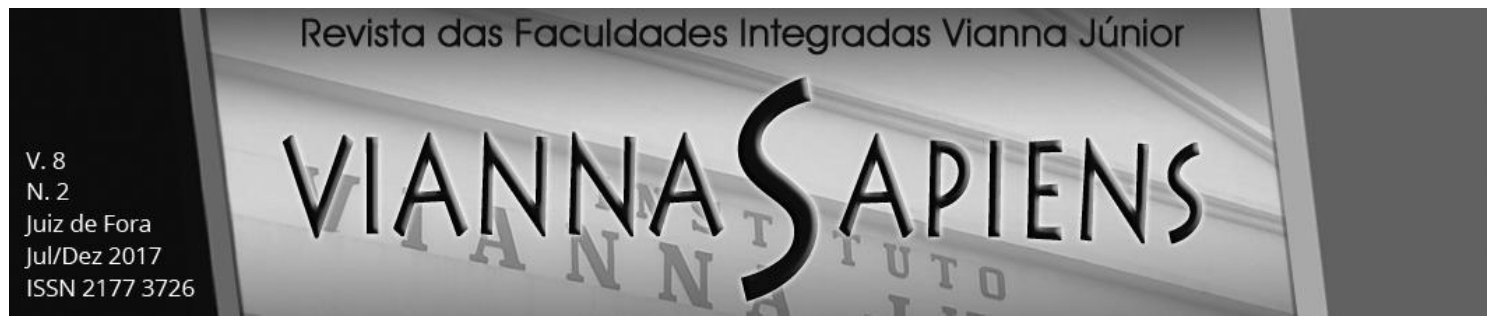

exploração sofrida pela biodiversidade, a negligência em relação ao devido respeito ao conhecimento tradicional e o interesse econômico inserido, que se sobrepõe a princípios e valores em diversos aspectos.

Em seguida, haverá um estudo de caso empírico sobre a copaíba, com escopo de fortalecer a proposições elencadas, uma vez que a copaíba é uma árvore cujas propriedades despertam olhares para sua exploração, haja vista que sua madeira é utilizada para produção de diversos itens e seu óleo é exaustivamente explorado em indústrias cosméticas, na fabricação de plásticos e aditivos para resina, vernizes e tintas.

Por fim, haverá a verificação das normas relacionadas à biodiversidade e ao patenteamento, demonstrando a relação entre eles e se há uma proposta de proteção eficaz.

\section{REFERENCIAIS TEÓRICOS E ESTRATÉGIA METODOLÓGICA}

A metodologia a ser aplicada se baseia nas descrições realizadas por Epstein e King (2013), acerca das pesquisas empíricas na seara jurídica, tendo por objetivo central a intenção de criticar a aplicação pura da legislação ao conceder patentes que possuem em sua composição, elementos que integram o conhecimento tradicional.

O objetivo primordial de uma pesquisa empírica consiste na coleta de dados que serão utilizados pelo pesquisador ou por terceiros, sendo os mesmos resumidos de forma a facilitar sua compreensão e, por fim, a realização de inferências descritivas ou causais, de modo que a utilização de dados/fatos conhecidos possibilitará 0 aprendizado de informações desconhecidas, as quais se deseja alcançar (EPSTEIN e KING, 2013). Conforme as alegações destes autores, os fatos que se tem acesso servem para aprender o que não se conhece, sendo seu resultado, passível de replicação, ou seja, qualquer pesquisador poderá compreendê-lo, verificá-lo e 


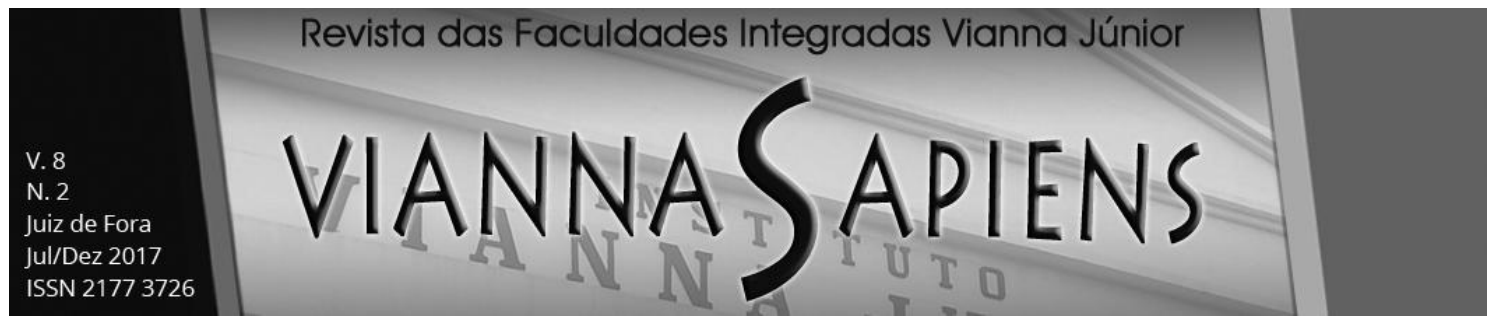

até mesmo vir a reproduzi-lo, sem informações adicionais por aquele que elaborou a pesquisa.

Dessa forma, far-se-á inferências descritivas e causais. A primeira consiste em avaliar informações já contidas, devendo o pesquisador, especificar o objeto a ser trabalhado, enquanto a segunda se propõe em questionar se há algum fator ou um conjunto dos mesmos que conduz a um resultado, havendo a possibilidade destes resultados se caracterizem como variáveis que assumem diferentes valores.

A maior meta é a verificação da suficiência ou não de proteção à biodiversidade diante dos argumentos traçados pela propriedade intelectual e a legislação vigente, considerando o TRIPS e a CBD, ambos incorporados pelo Ordenamento Jurídico.

Também se faz necessária a elaboração de uma construção crítica sobre o trabalho realizado por órgãos administrativos, verificando a presença de quesitos de legalidade e legitimidade ao conceder patentes cujos componentes integram a biodiversidade e isso se torna mais visível ao questionar o conceito de identidade moderna e o reconhecimento de outrem, como sujeito de direitos e obrigações dentro de uma sociedade.

Em Bankowski, a busca por viver uma vida plena pode ser vislumbrada pelo seguimento de extremos, seja a lei em si ou o amor em si. Contudo, alcançar a plenitude não significa excluir um e aderir ao outro em sua totalidade, haja vista que o amor, que está diretamente ligado a uma ideia de compaixão, e o direito, voltado para a aplicação de regras, não se excluem, pelo contrário, através da argumentação e de uma atenção para a especialidade de cada caso concreto, se encaixam e permitem que se viva plenamente em harmonia.

Para melhor explicar, Bankowski remete à Antígona, obra de Sófocles, na qual há uma guerra cujo objetivo é alcançar o trono de Tebas. Os dois filhos de Édipo se matam, havendo então uma norma que proibia o enterro de Polinices, devido ao seu posicionamento no conflito. Sua irmã é a protagonista 


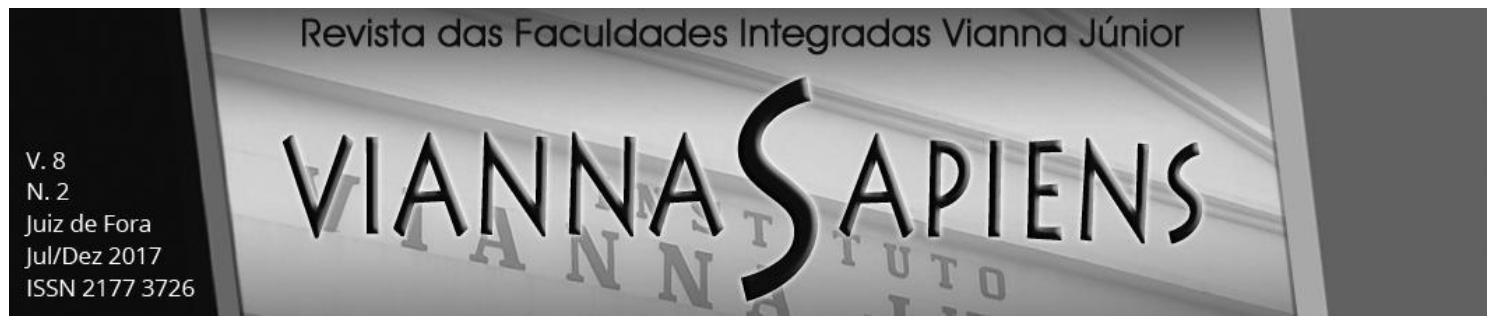

da obra que traz em seu personagem, a representação do amor e dedicação à família, movida por um sentimento de compaixão diante de seu irmão, morto como inimigo do governo e indigno de um enterro conforme os costumes daquela sociedade. Em contrapartida, Creonte, seu tio, se caracteriza como o Estado, afirmando a todo o momento, a necessidade de aplicação total da lei, sem qualquer tipo de ponderação, pois ainda que Polinices fosse seu sobrinho, seu corpo deveria permanecer largado a esmo, uma vez que esta era a previsão no édito como o destino para o combatente de sua oposição.

$\mathrm{Na}$ defesa por suas escolhas, eles perderam a humanidade que deveriam preservar. Viver o direito não significa se restringir ao legalismo, pois este se manifesta a partir do momento em que a noção de confiança às regras ultrapassa os limites. No legalismo a única análise que é realizada gira em torno da aplicação de regras, não interessando a forma com que as mesmas serão estabelecidas. Tratando-se do amor, este se volta para uma forma de vida que negligencia a necessidade de limites e regras que são essenciais para conduzir o modo de viver em sociedade.

Entender as aspirações existentes por detrás das regras permite ver que a letra da lei não precisa ser seguida a qualquer custo (BANKOWSKI, 2007, p. 73). Regras existem para ajudar a compreender e podem ser reformuladas sob a luz do aprendizado que elas proporcionam e o fato de deixar de segui-las não significa um ato de hipocrisia, mas a certeza de que a legalidade se difere do legalismo e que as regras precisam ser mudadas para um benefício maior de determinada aspiração.

Para melhor explicar a harmonia entre a lei do amor e o amor da lei, Bankowski utiliza um método explicativo o qual denomina de "raciocínio parabólico", valendo-se de uma narrativa bíblica na qual um escriba, com intuito de condenar Jesus perante a sociedade, o questionou acerca da forma a ser seguida para conquistar a vida eterna. Ciente de sua postura, Jesus o perguntou o que estava escrito na lei e ele o respondeu que era amar a Deus sobre todas as coisas e o próximo como a si mesmo. Diante desta resposta, 


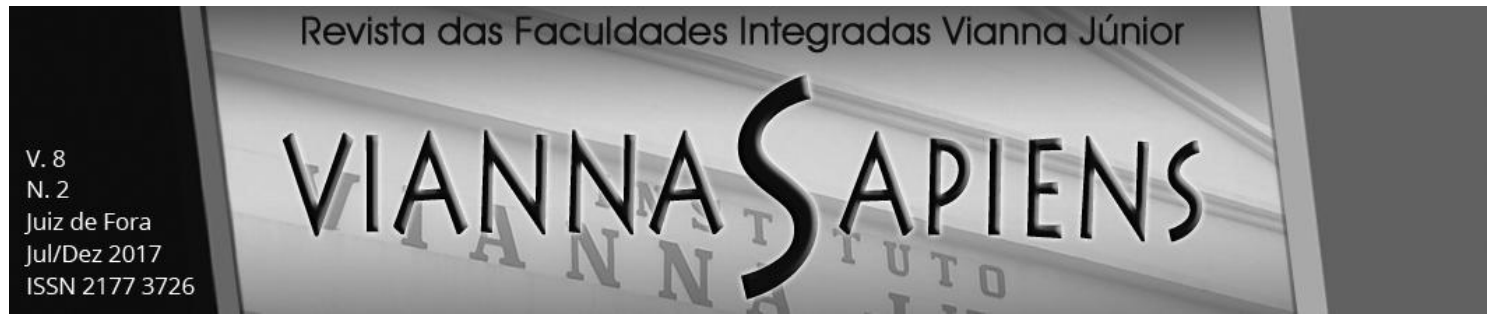

algumas perguntas tornam-se pertinentes: quem é o próximo? Como reconhecê-lo? O que fazer em seu favor? Para the mostrar quem era o próximo, Jesus usou a parábola do bom samaritano:

\begin{abstract}
Um homem descia de Jerusalém a Jericó, e caiu nas mãos de salteadores, os quais o despojaram e espancando-o, se retiraram, deixando-o meio morto. Casualmente, descia pelo mesmo caminho certo sacerdote; e vendo-o, passou de largo. De igual modo também um levita chegou àquele lugar, viu-o, e passou de largo. Mas um samaritano, que ia de viagem, chegou perto dele e, vendo-o, encheu-se de compaixão; e aproximando-se, atou-lhe as feridas, deitando nelas azeite e vinho; e pondo-o sobre a sua cavalgadura, levou-o para uma estalagem e cuidou dele. No dia seguinte tirou dois denários, deu-os ao hospedeiro e disse-lhe: Cuida dele; e tudo o que gastares a mais, eu to pagarei quando voltar. Qual, pois, destes três te parece ter sido o próximo daquele que caiu nas mãos dos salteadores? Respondeu o doutor da lei: Aquele que usou de misericórdia para com ele. Disse-lhe, pois, Jesus: Vai, e faze tu o mesmo.(LUCAS 10, 30-37)
\end{abstract}

Talvez esse tenha sido o único caminho para que este homem pudesse passar e neste momento, ladrões o roubaram e feriram. Cada uma das tribos de Israel possuía uma cor de roupa, facilitando sua identificação, mas passando pelo mesmo caminho um sacerdote e um levita, nenhum deles se compadeceu. Ao passar um samaritano, este saiu de sua zona de conforto, cuidou do homem ferido e usou de misericórdia com ele.

Fato é que os samaritanos não conviviam com os judeus, sendo considerados inferiores a estes por serem descendentes de populações estrangeiras, mas foi um deles que reconheceu a necessidade de romper com as imposições legais e amou o próximo como a si mesmo. O direito não é provedor de total segurança, ressaltando que o judeu estava amparado pela lei, mas esta não o alcançou. Ele precisou de alguém de fora para sustentá-lo e isso mostra a necessidade do amor para se manter a lei, pois ninguém é totalmente forte, precisando considerar a existência de igualdade em nossa vulnerabilidade (BANKOWSKI, 2007, p. 111). 


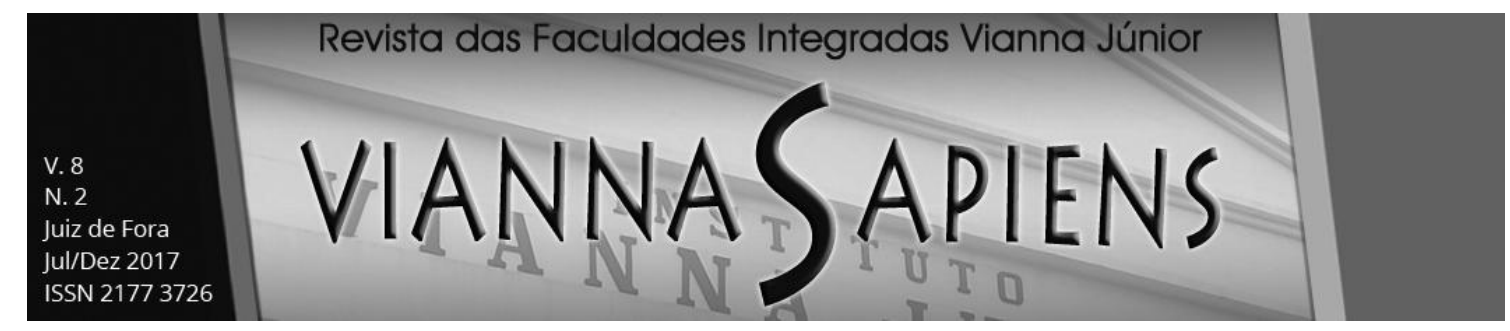

A questão aqui é que Deus, a expressão da racionalidade universal, que é o sujeito concreto, jaz à rua em estado de deterioração. É ele quem é auxiliado pelo bom Samaritano. $O$ Samaritano vê naquela figura não somente o mendigo, mas a própria transfiguração do Divino. E, por causa disso, ele sabe a decisão a tomar. (BANKOWSKI, 1996-1997, tradução livre). ${ }^{2}$

Dessa forma é possível utilizar um raciocínio parabólico para reconstruir a ideia de legalidade, de modo que o amor se faça presente em equilíbrio com a lei.

Seguindo o raciocínio de Charles Taylor, há a estruturação de uma narrativa que é elementar para o desenvolvimento da identidade humana, uma vez que se considera que a mesma consiste em uma ligação total entre identidade e moralidade. Mas o que é moral? É preciso perceber que a moralidade vai muito além de justiça, respeito à vida e bem-estar. O que Taylor propõe atingir consiste na própria dignidade e o fator que leva o ser humano a desejar uma vida satisfatória:

Há questões sobre como vou levar a minha vida que remetem ao aspecto de que tipo de vida vale a pena ter ou que tipo de vida vai cumprir a promessa implícita em meus talentos particulares, nas exigências incidentes sobre alguém com minha capacidade, ou do que constitui uma vida rica e significativa em contraposição a uma vida voltada para questões secundárias ou trivialidades. (TAYLOR, 1997, p. 29)

Quando Taylor questiona quais são os elementos formadores de nossa identidade, ele deseja demonstrar que, saber quem somos é uma espécie de saber acerca da posição em que nos colocamos. Logo, a identidade cria uma estrutura dentro da qual se pode determinar a posição que defendemos em questões sobre o que é bom ou válido, admirável ou valoroso.

\footnotetext{
2"The point here is that it is God, the expression of universal rationality, Who is the concrete particular, lying injured on the street. It is He who is aided by the good Samaritan. The Samaritan sees not just the beggar, but in that beggar he sees the Divine. And it is because of that he knows what to do." (BANKOWSKI, 1996-1997).
} 


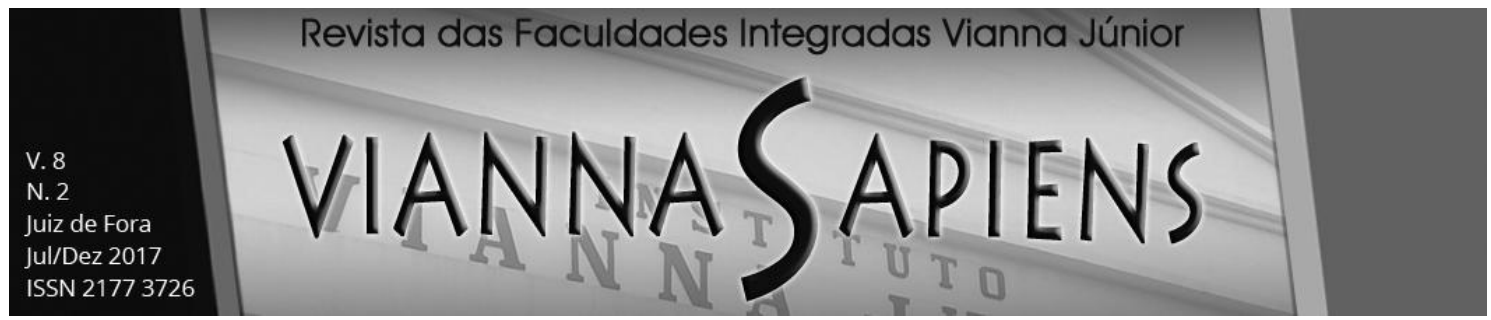

Uma das mais básicas aspirações de um indivíduo consiste na necessidade de estar vinculado, conectado com aquilo que ele considera bom, de grande importância ou que possui valor fundamental. Ainda que haja uma série de bens, para alguns deles se atribui superioridade e isto significa que este bem proporciona os traços que são a direção de sua vida (TAYLOR, 1997).

Sendo assim, ao seguir os referenciais teóricos de Zenon Bankowski e Charles Taylor, além da estrutura metodológica de Epstein e King, haverá uma análise acerca do patenteamento de substâncias componentes do conhecimento tradicional, considerando o conteúdo do TRIPS e da CBD, com seus mais relevantes princípios: uso sustentável da biodiversidade; conservação de recursos biológicos; compartilhamento de benefícios.

\section{A RIQUEZA DO PRATRIMÔNIO GENÉtICO, O PROCESSO DE BIOPROSPECÇÃO E A BIOPIRATARIA: repensando as construções normativas}

Considerando que o Brasil possui uma extensão territorial que ocupa praticamente a metade da América do Sul, é notório que este fator gera uma contribuição direta para que haja diversas zonas climáticas no território nacional, tais como: zona temperada, localizada no sul do país; zona tropical na região sudeste; zona equatorial na região amazônica (SENE et al, 2013).

A variedade climática existente influencia diretamente na riqueza ecológica do território, que proporciona a origem aos distintos biomas, havendo a Floresta Amazônica como a maior floresta tropical do mundo, o Cerrado, com suas savanas, a Mata Atlântica e sua umidade, a Caatinga e o Pantanal, sem contar a imensidão de sua costa marinha, com seus pântanos, manguezais, entre outros, tornando o Brasil o detentor da maior biodiversidade do planeta. 


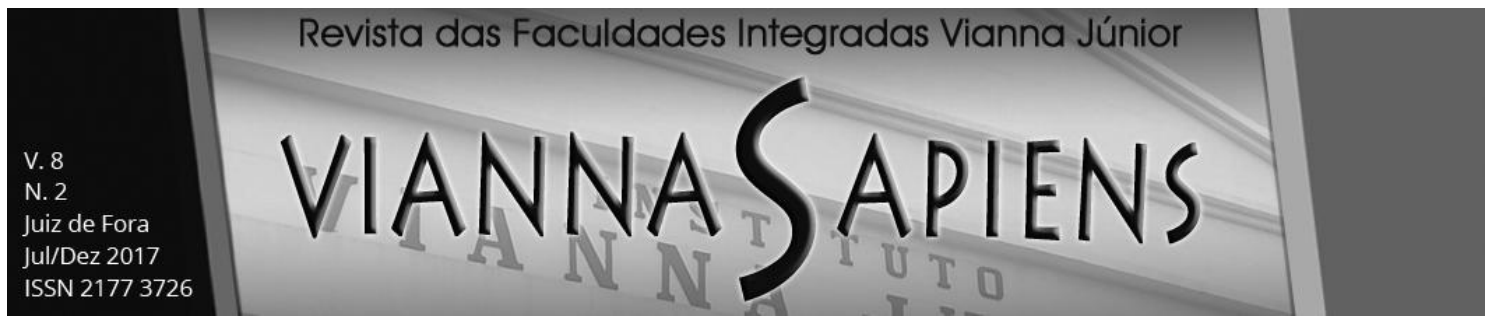

Ademais, o país concentra em seu território uma sociobiodiversidade, haja vista que é formado por indígenas que se encontram nas cinco regiões do país, além de comunidades quilombolas, seringueiras e caiçaras, com representativo acervo de conhecimentos tradicionais, sendo estes, também, integrantes da biodiversidade.

Tais comunidades estruturaram sua identidade através de uma forma sustentável de viver, pois toda sabedoria que possuem se origina na observação e experiência com a natureza, ressaltando que estes povos se mantêm nessa forma de vida também como uma das consequências do processo de colonização, exploração e formação do estado brasileiro, pelas demarcações e expansões territoriais, escravidões, fugas, além das missões religiosas oriundas do movimento de contrarreforma na Europa, em meados do século XVI (CUNHA, 2006).

Dessa forma, há o despertar de um interesse mundial ao redor de um país megadiverso, principalmente pelo fato de se encontrar elevado potencial para produção de medicamentos, matéria-prima para indústrias e substâncias que já se encontram escassas ou inexistentes em outros lugares do mundo. Daí a existência de uma série de instituições cujas normas visam o cuidado com a preservação da megadiversidade, sem negligenciar a importância que o conhecimento de seu patrimônio genético possui para a cura de incontáveis doenças, além de outras propriedades que são relevantes para o benefício da sociedade.

A Convenção sobre Diversidade Biológica (CBD), assinada no período da Conferência das Nações Unidas sobre Meio Ambiente e Desenvolvimento, no Rio de Janeiro em 1992, apresenta a necessidade de se observar um valor intrínseco da biodiversidade, sua relevância para a evolução e manutenção dos sistemas essenciais para a vida e a preservação, a prevenção e a redução da perda da diversidade biológica.

Ademais, esta Convenção manifesta a existência de uma dependência dos recursos biológicos das mais variadas comunidades tradicionais, 


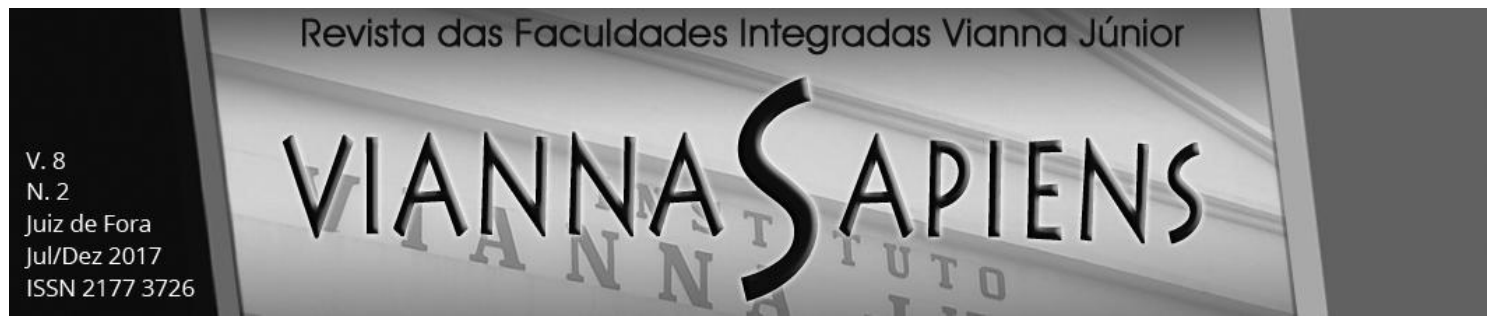

ressaltando a importância do conhecimento das populações indígenas, com suas formas de vida tradicionais, alegando ser desejável o compartilhamento equitativo de benefícios oriundos deste conhecimento tradicional, além da divisão de inovações e de práticas que se caracterizam como relevantes para a manutenção da biodiversidade, somado ao uso de uma forma sustentável de seus componentes.

Sendo assim, destacam-se como objetivos da CBD, a conservação da diversidade biológica, a utilização sustentável de seus componentes e a repartição de modo justo e equitativo dos benefícios derivados da utilização dos recursos genéticos, conforme seu artigo 1․ Ressalte-se que essa utilização sustentável abarca a proteção e encorajamento da utilização conforme os costumes de recursos biológicos compatíveis com as práticas culturais tradicionais que estão em acordo com as exigências de conservação ou utilização sustentável. Em relação aos povos tradicionais e sua sabedoria derivada do próprio contato com a natureza, o artigo $8^{\circ}$, J, da CBD traz o seguinte enunciado:

Cada Parte Contratante deve, na medida do possível e conforme o caso:

j) Em conformidade com sua legislação nacional, respeitar, preservar e manter o conhecimento, inovações e práticas das comunidades locais e populações indígenas com estilo de vida tradicionais relevantes à conservação e à utilização sustentável da diversidade biológica e incentivar sua mais ampla aplicação com a aprovação e a participação dos detentores desse conhecimento, inovações e práticas; e encorajar a repartição equitativa dos benefícios oriundos da utilização desse conhecimento, inovações e práticas.

Além desse dispositivo elencado na CBD aparentemente propor o respeito e a manutenção da forma de vida de povos tradicionais, bem como a preservação de seu saber, somado à ênfase ao compartilhamento de benefícios, o Acordo Sobre Aspectos Dos Direitos de Propriedade Intelectual Relacionados ao Comércio (TRIPS) menciona de forma objetiva e taxativa, 


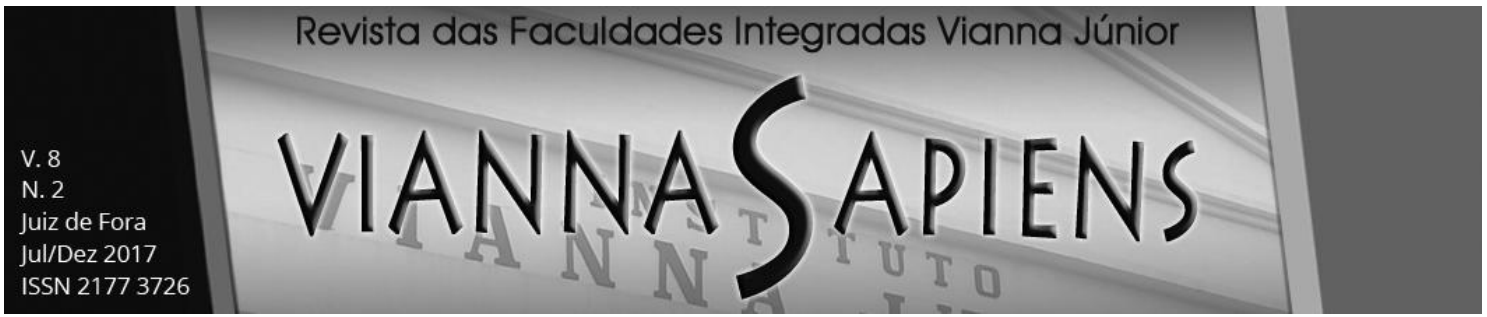

quais são os elementos que não podem ser patenteados em seu artigo 27, item 3, alínea b. Vejamos:

3. Os Membros também podem considerar como não patenteáveis:

b) plantas e animais, exceto microorganismos e processos essencialmente biológicos para a produção de plantas ou animais, excetuando-se os processos não-biológicos e microbiológicos. Não obstante, os Membros concederão proteção a variedades vegetais, seja por meio de patentes, seja por meio de um sistema sui generis eficaz, seja por uma combinação de ambos. O disposto neste subparágrafo será revisto quatro anos após a entrada em vigor do Acordo Constitutivo da OMC.

No mesmo sentido, o artigo 8ำ da lei 9.279/96 prevê os requisitos para que seja admissível a propositura de um pedido de patente, sendo eles: a invenção que atenda aos requisitos de novidade, atividade inventiva e aplicação industrial.

No que concerne à utilização da bioprospecção, esta é visualizada como uma das formas de extração de valores econômicos da diversidade biológica, sendo seu termo passível de entendimento como uma busca sistemática por organismos, genes, enzimas, compostos, processos e partes originárias de seres vivos, que possuam em si, potenciais econômicos e, sejam aplicados ao desenvolvimento de algum produto (SACCARO JÚNIOR, 2011). A antiga Medida Provisória nำ 2.186/01, apresentava em seu artigo 7ํㅡ, VII, que a bioprospecção se configura como uma atividade exploratória que visa identificar componente do patrimônio genético e informação sobre conhecimento tradicional associado, com potencial de uso comercial.

Havia uma estimativa no ano de 2003 que aproximadamente 40\% dos medicamentos que se encontravam disponíveis na terapêutica se originavam por substâncias naturais, sendo $25 \%$ de plantas, $13 \%$ de microorganismos e 3\% de animais (CALIXTO, 2003). Segundo Saccaro Júnior (2011), tais valores cresceram cerca de $50 \%$ e em relação aos medicamentos que combatem o 


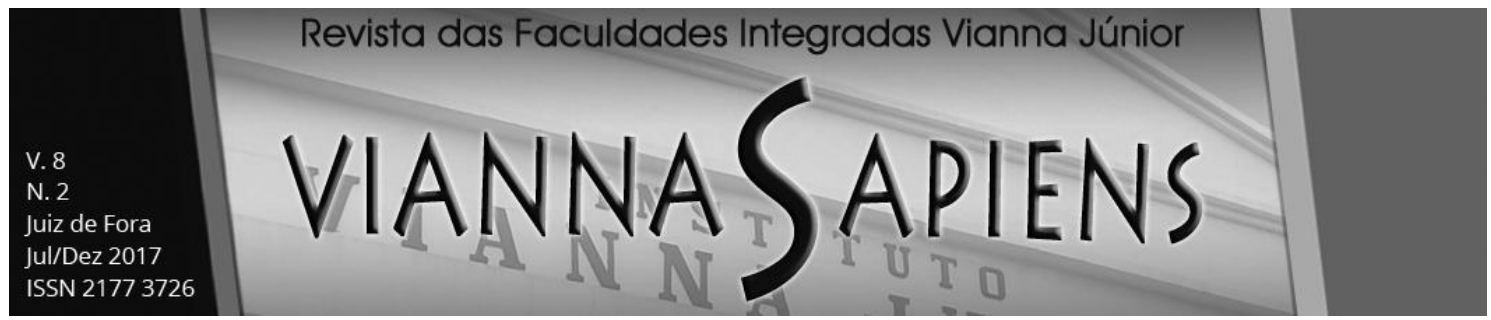

câncer, acredita-se que dois terços dos mesmos sejam de origem natural, oriundos de organismos marinhos e terrestres.

Quanto à biopirataria, é possível compreendê-la como o ato de apropriar-se de recursos genéticos, das mais variadas formas de conhecimento tradicional dos povos que se encontram em locais nos quais a diversidade biológica é algo abundante. Sendo assim, a biopirataria se caracteriza pela apropriação de um recurso genético, seja ele animal seja ele vegetal, ou do próprio conhecimento tradicional atrelado à diversidade biológica, sem que ocorra a devida autorização do Estado do qual se extraiu tal recurso ou da própria comunidade que o elaborou, aperfeiçoou e o transmitiu de geração em geração.

Inicialmente, ao relacionar as normas pertinentes ao conhecimento tradicional e o atual registro de patentes, pode-se verificar uma proposta relacionada à proteção da biodiversidade apresentada pela CBD, uma restrição ao patenteamento, que abarca de forma taxativa os elementos vedados e o processo de bioprospecção, caracterizado este pela extração e utilização de integrantes da biodiversidade e do conhecimento tradicional a fim de haver recursos genéticos que produzam renda. Importa reiterar que não há, em momento algum, o intuito de vedar a utilização de práticas e métodos tradicionais, uma vez que seu uso não ofende os direitos pertencentes aos povos tradicionais.

O problema se concentra no ato de registrar uma patente que se apropria das descobertas, experiências e costumes destes povos, ignorando suas necessidades mais básicas e principalmente, desrespeitando o modo de vida por eles adotado. Comunidades tradicionais acumulam seu conhecimento e sabedoria no decorrer dos séculos, especialmente pela observação que realizam da natureza, transmitindo tais aprendizados para cada geração e sempre acrescentando algo a mais, de modo simples, valendo-se da oralidade para ensinar. 


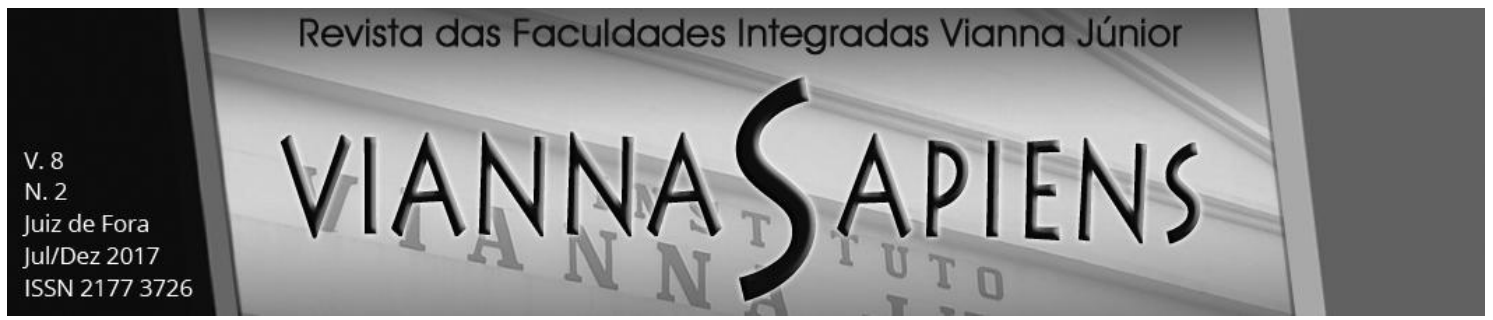

O desenvolvimento de sua medicina é algo que frequentemente se encontra bombardeado pela biopirataria, uma vez que inúmeros medicamentos e cosméticos com alto índice de vendas no mercado são oriundos do aprendizado destes povos, sendo possível mencionar uma série de elementos que pertencem à biodiversidade e são apropriados por empresas, possuindo patentes não somente no Brasil, mas em muitos países pelo mundo, como é o caso do jaborandi, veneno de jararaca, cupuaçu, açaí, andiroba, dentre outros.

Portanto, mais uma vez se faz necessário apresentar algumas indagações, tais como: qual é a forma de compatibilizar o conhecimento tradicional e a inovação? Como solucionar os casos de biopirataria em um espaço no qual há o registro de patentes? Não há uma resposta pronta e acabada para estas indagações, mas sim, um ponto de partida que permite uma visão mais crítica acerca do processo de patenteamento e o discurso de proteger algo que por si só, possui potencial.

\section{UM ESTUdo SOBRE A COPAÍBA E A VERIFICAÇÃo DE SEU PATENTEAMENTO}

Partindo das considerações acerca da biodiversidade, do tradicional e do avanço econômico gerado pelo patenteamento de componentes naturais, este trabalho seguirá por meio de sua estratégia metodológica, um estudo empírico sobre a Copaiferalangosdorffii, popularmente conhecida como copaíba, mas também denominada de bálsamo, caobi, capaíba, copaúva, oleiro, pau-d’óia, pau-óleo-do-sertão, podoi, dentre outros (CARVALHO, 2003).

A copaíba pertence à classe das dicotiledôneas e à família Caesalpiniaceae, sendo encontrada em todas as regiões do país, mas preponderantemente na região sudeste. Seguindo um viés metodológico, a Copaifera será chamada de copaíba ao longo deste trabalho, que apresentará informações relacionadas à importância desta árvore, o desenvolvimento do 


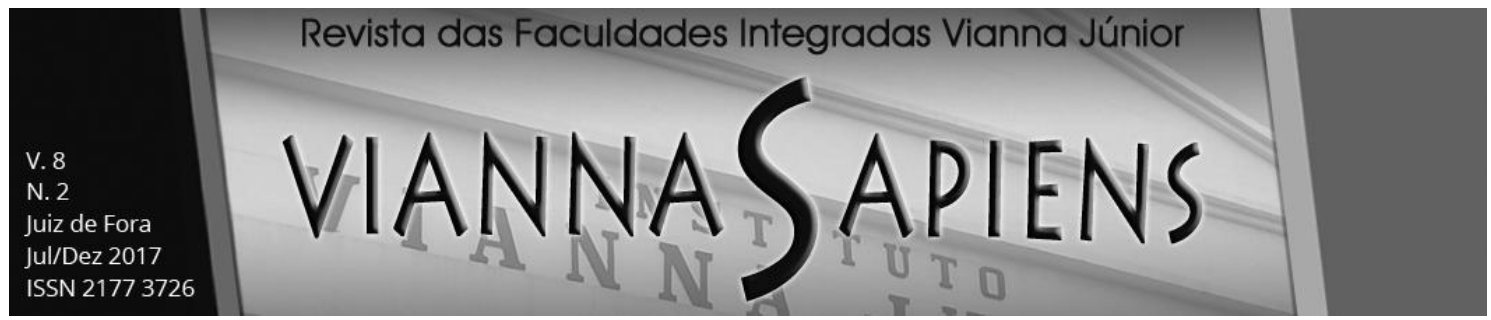

conhecimento tradicional através de suas propriedades e três tabelas compostas por algumas das patentes que contêm a copaíba.

Inicialmente, torna-se relevante abordar que na copaíba há o potencial para a criação e utilização de inúmeros itens, como é o caso da utilização de sua madeira para a construção civil e construção naval; seu consumo para produção de energia, haja vista que a madeira da copaíba possui alto teor de lignina, excelente na elaboração de álcool, coque e carvão (PAULA, 1981). Além disso, esta árvore possui constituintes químicos, considerando que suas sementes apresentam alto conteúdo de um polissacarídeo formado por glicose; óleo, que é extraído por intermédio de incisões ou perfurações em seu tronco, sendo que ele flui de modo muito puro, que somente é possível sua utilização em seu estado natural, ou seja, sem o refinamento, principalmente em barcos a motor e como combustível caseiro; por fim, a utilização medicinal, uma vez que a resina, a casca e o óleo da copaíba são utilizados na forma de chá (CORREA, 1978), além do fato de que esta espécie tem efeito antisséptico, cicatrizante, carminativo, expectorante, diurético, laxativo, estimulante, emoliente e tônico (BARROS, 1982; TESKE E TRENTINI, 1997).

Sendo assim, através da copaíba é possível solucionar problemas pulmonares, dentre eles, a tosse e a bronquite, disenteria, incontinência urinária, tratar-se de cura de feridas, de eczemas, de psoríase e urticária, além de ter efeito cicatrizante em pequenas irritações do couro cabeludo. Em relação a seu óleo, este é usado em infusão para a cura de resfriados (BRANDÃO, 1991), somado à casca, em uma mistura com cachaça pelo período de uma semana, em tratamentos de bronquites (GAVILANES E BRANDÃO, 1992).

Tratando-se da zona rural, especialmente a nordestina, o óleo da copaíba possui a função de elemento cicatrizante no corte do umbigo de recém-nascidos. Já os povos indígenas localizados na região amazônica possuem o costume de usar o óleo da copaíba (no tupi guarani é a "kupa'iwa"), para combater doenças em suas peles e para realizar tratamento de picadas de insetos. Há uma tradição dos povos indígenas também utilizarem, assim 


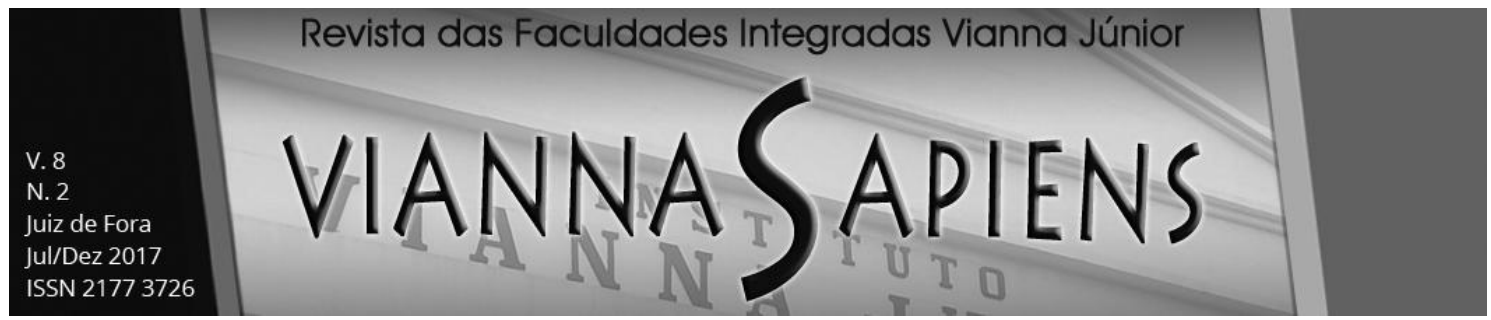

como os nordestinos, o óleo da copaíba no umbigo de recém-nascidos e para a cura de ferimentos.

Ademais, quando eles se feriam em guerras, derramavam o óleo em seu corpo e se deitavam em esteiras para sua recuperação (VEIGA JÚNIOR, 2002). Vale ressaltar que os colonos descobriram outras formas de aplicações terapêuticas, tanto em vias urinárias quanto respiratórias, além do combate ao tétano e infecções da pele. A copaíba encontra-se na lista das espécies que correm perigo de extinção no Estado de São Paulo (ITOMAN et al., 1992), ressaltando que sua conservação genética feita no estado supracitado por populações-bases ex situ (SIQUEIRA E NOGUEIRA, 1992) e in situ (SILVA, 1986).

Pelo viés metodológico desenvolvido através dos ensinamentos de Epstein e King, no qual há a realização de uma coleta de dados, posteriormente se elabora o resumo das informações adquiridas para que se produzam as inferências, far-se-á uma busca acerca da copaíba no banco de dados da Organização Mundial de Propriedade Intelectual (OMPI), através do site <www.wipo.int>, que dentre as diversas opções apresentadas se utilizará o item "Reference", que gerará o acesso ao link "PatentsCope". Após obtê-lo, partir-se-á para a opção denominada "Access the PATENTSCOPE database". Imediatamente surgirá uma nova guia, com possibilidades de filtros para a realização da pesquisa em seu banco de dados. Com o objetivo de encontrar o maior número de patentes que contenha a copaíba como elemento, vale-se da opção "Any Field" e então se digita na ferramenta de busca a palavra "copaíba". Logo, resultará o total de sessenta e uma patentes. Todas estas foram analisadas de forma criteriosa para melhor produzir inferências, valendose do critério temporal para avaliá-las, entre 1993 e 2015.

Através do método desenvolvido para análise das patentes trabalhadas, todo pesquisador é capaz de chegar ao mesmo resultado aqui apresentado, uma vez que se trata de algo passível de replicação, sem que seja necessária a concessão de qualquer informação adicional. 


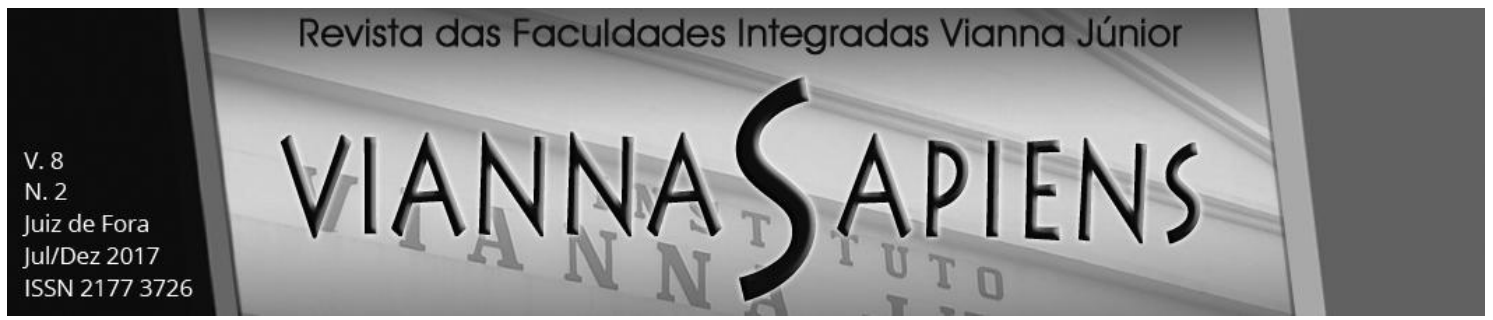

Dessa forma, encontrar-se-á dentro das sessenta e uma patentes, três que já se encontram em domínio público, quarenta e oito patentes que possuem a copaíba como substância elementar para o resultado final de seu produto/medicamento, treze delas possuem a copaíba como algo que poderá ser substituído por outro, como óleo de macadâmia, por exemplo, sete patentes constituem-se apenas da mistura de produtos naturais, sendo o total de cinquenta patentes, aquelas que utilizam na elaboração de seu produto, o óleo da copaíba.

Pelo excesso do patenteamento valendo-se deste óleo em sua composição, seguirão abaixo três tabelas, apresentando em cada uma das patentes que as integram, o seu nome, número, país de origem e data. Observando cada uma das patentes que possuem a copaíba, há uma divisão em três grandes grupos, a saber: o primeiro, contendo a copaíba como elemento central para o desenvolvimento do produto desejado; o segundo grupo tem-na como algo passível de substituição, ou seja, outros óleos poderão ser explorados no lugar da copaíba e o resultado desejado será o mesmo; por fim, o terceiro grupo é composto por patentes que apenas misturam produtos naturais, sem qualquer tipo de invenção.

\begin{tabular}{|l|l|l|}
\hline $\begin{array}{l}\text { TABELA 1 - ÓLEO DE COPAÍBA COMO } \\
\text { ELEMENTO ESSENCIAL DA PATENTE }\end{array}$ & $\begin{array}{l}\text { NÚMERO DE } \\
\text { REGISTRO }\end{array}$ & $\begin{array}{l}\text { PAÍS DE ORIGEM E } \\
\text { DATA }\end{array}$ \\
\hline Composição para xampu & PI 9302003 & Brasil - 28/09/1993 * \\
\hline $\begin{array}{l}\text { Composição desodorante adequada para a } \\
\text { aplicação tópica na pele humana }\end{array}$ & PI 9501286 & Brasil - 31/10/1995 * \\
\hline Composição natural para a cura do câncer & PI 9705573 & Brasil - 06/07/1999 \\
\hline $\begin{array}{l}\text { Composiciones de fragancia para el proceso de } \\
\text { lavado con CO2 }\end{array}$ & 2272702 & Espanha - 01/05/2007 \\
\hline $\begin{array}{l}\text { Fração volátil de oleoresina da copaíba, } \\
\text { processo de obtenção da mesma, fração volátil } \\
\text { microencapsulada, processo de encapsulação } \\
\text { da fração volátil e seus usos terapêuticos }\end{array}$ & PI 0600453 & Brasil - 23/10/2007 \\
\hline Máscara rejuvenescedora de argila em pó & PI 0603411 & Brasil - 26/12/2007 \\
\hline $\begin{array}{l}\text { Composição medicamentosa para tratamento de } \\
\text { psoríase }\end{array}$ & PI 0603600 & Brasil - 15/04/2008 \\
\hline $\begin{array}{l}\text { Composição natural e processo de tratamento de } \\
\text { insumos para confecção de artesanato usando } \\
\text { dita composição }\end{array}$ & PI 0700960 & Brasil - 09/09/2008 \\
\hline
\end{tabular}




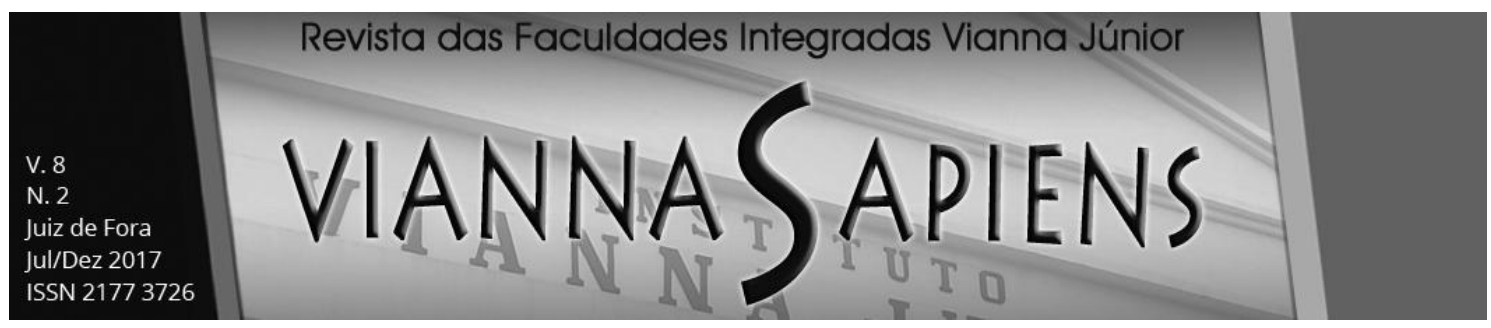

\begin{tabular}{|c|c|c|}
\hline $\begin{array}{l}\text { Formulação medicinais, veterinárias e } \\
\text { cosméticas utilizando o extrato obtido do caldo } \\
\text { de cana de açúcar fermentado, contendo } \\
\text { diversos compostos bioativos naturais, } \\
\text { complementados ou não com extratos vegetais }\end{array}$ & PI07036999 & Brasil - 23/09/2008 \\
\hline $\begin{array}{l}\text { Processo para fabricação de fortificante } \\
\text { pulmonar }\end{array}$ & PI 0706194 & Brasil - 28/07/2009 \\
\hline $\begin{array}{l}\text { Sabonete para banho em barra repelente de } \\
\text { insetos }\end{array}$ & PI 0800726 & Brasil -08/09/2009 \\
\hline $\begin{array}{l}\text { Delivery system and method of treating or } \\
\text { preventing otitis media }\end{array}$ & 1326584 & Portugal - 26/11/2009 \\
\hline Shampoo em barra repelente de insetos & PI 0803945 & Brasil - 19/01/2010 \\
\hline Condicionador de cabelo repelente de insetos & PI 0803941 & Brasil - 19/01/2010 \\
\hline $\begin{array}{l}\text { Hidratante corporal em loção repelente de } \\
\text { insetos }\end{array}$ & PI 0803940 & Brasil - 19/01/2010 \\
\hline Espuma de banho repelente de insetos & PI 0803939 & Brasil $-19 / 01 / 2010$ \\
\hline Shampoo líquido repelente de insetos & PI 0804327 & Brasil - 19/01/2010 \\
\hline Sais de banho espumante repelente de insetos & PI 0804328 & Brasil $-19 / 01 / 2010$ \\
\hline $\begin{array}{l}\text { Lenço umedecido de bolso descartável repelente } \\
\text { de insetos }\end{array}$ & PI 0805486-0 & Brasil - 24/08/2010 \\
\hline Cera depilatória e seu processo de obtenção & PI 0902170 & Brasil - 13/01/2011 \\
\hline $\begin{array}{l}\text { Processo para preparação de composição } \\
\text { cosmética com propriedades farmacêuticas de } \\
\text { elevada absorção; método para prevenção e/ou } \\
\text { tratamento de inflamações da pele de } \\
\text { mamíferos, utilizando composição cosmética } \\
\text { com propriedades farmacêuticas de elevada } \\
\text { absorção, método para regenerar tecido cutâneo } \\
\text { submetido à radioterapia, utilizando composição } \\
\text { cosmética com propriedades farmacêuticas de } \\
\text { elevada absorção }\end{array}$ & PI 0904577 & Brasil - 14/01/2011 \\
\hline $\begin{array}{l}\text { Composição de cuidado do tecido, composiçães, } \\
\text { pó de poluretanouréia, método para a extensão } \\
\text { da concretização do perfume em um tecido, } \\
\text { método de aumento da retenção do formato da } \\
\text { vestimenta, método para aumentar a facilidade } \\
\text { das propriedades de cuidado de um tecido, } \\
\text { método para aumentar a facilidade das } \\
\text { propriedades de cuidado de um tecido, método } \\
\text { para proporcionar propriedade anti-manchas a } \\
\text { um tecido, métodos para a preparação do pó de } \\
\text { poluiretanouréia, método para o tingimento de } \\
\text { uma composição em pó e método para prolongar } \\
\text { a concretização do perfume em uma composição }\end{array}$ & PI 0706934 & Brasil - 03/03/2011 \\
\hline $\begin{array}{l}\text { Aplicações de óleos essenciais micro- } \\
\text { encapsulados }\end{array}$ & PI 0707936 & Brasil - 29/03/2011 \\
\hline $\begin{array}{l}\text { Emulsão preparatória aplicada a serviços de } \\
\text { manicure e pedicure }\end{array}$ & PI 0903845 & Brasil - 31/03/2011 \\
\hline $\begin{array}{l}\text { Hidratante corporal em barra repelente de } \\
\text { insetos }\end{array}$ & PI 0800228 & Brasil - 07/04/2011 \\
\hline $\begin{array}{l}\text { Processo para obtenção de tônico capilar e } \\
\text { tônico capilar }\end{array}$ & PI 0800228 & Brasil - 20/04/2011 \\
\hline
\end{tabular}




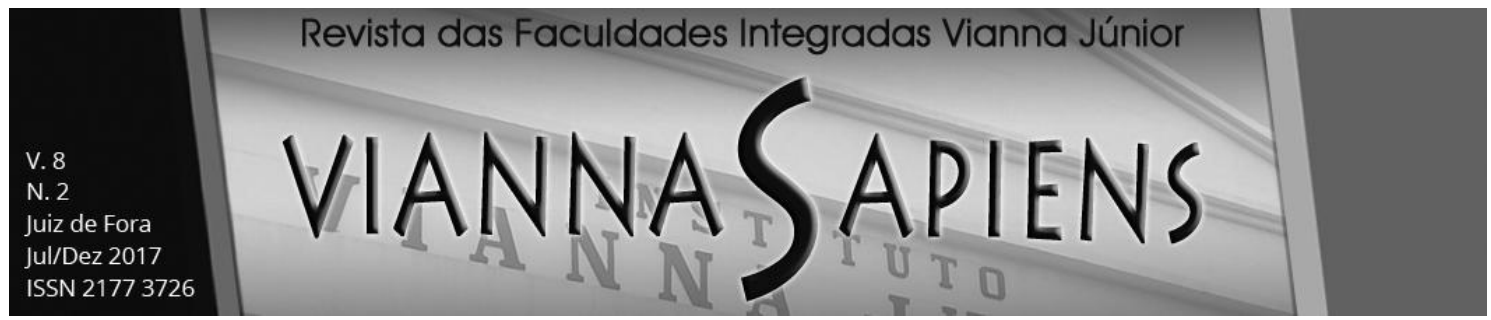

\begin{tabular}{|c|c|c|}
\hline $\begin{array}{l}\text { Composição farmacêutica a base de óleo de } \\
\text { copaíba padronizado (copaiferassp) para } \\
\text { tratamento de afecções ginecológicas }\end{array}$ & PI 1004276 & Brasil - 28/02/2012 \\
\hline $\begin{array}{l}\text { Process for manufacturing product for treating } \\
\text { psoriasis and product for treating psoriasis }\end{array}$ & WO/2014/036620 & Brasil - 13/03/2014 \\
\hline $\begin{array}{l}\text { Composição repelente-hidratante, à base de } \\
\text { óleos vegetais e óleos essenciais puros, } \\
\text { contendo extratos proibióticos procedentes da } \\
\text { cultura do kefir, processo para preparação da } \\
\text { composição repelente-hidratante à base de óleos } \\
\text { essenciais puro contendo extratos proibióticos } \\
\text { procedentes da cultura do kefir }\end{array}$ & 102012016205 & Brasil - 05/08/2014 \\
\hline $\begin{array}{l}\text { Nanofibras poliméricas incorporadas com óleos } \\
\text { essenciais e uso das mesmas }\end{array}$ & 102012202812 & Brasil - 26/08/2014 \\
\hline $\begin{array}{lcr}\text { Composiciones } & \text { de } & \text { perfume } \\
\text { quecomprendenmezclasespeciales } & \text { de } \\
\text { diastereómeros de } & \text { 2-isobutil-4-metil-tetrahidro- } \\
2 \mathrm{H} \text {-piran-4-al } & & \\
\end{array}$ & 2498942 & Espanha - 26/09/2014 \\
\hline $\begin{array}{l}\text { Composição química para spray antimicrobiano } \\
\text { orgânico }\end{array}$ & 102012032348 & Brasil - 29/10/2014 \\
\hline $\begin{array}{l}\text { Processo de fabricação e formulação de } \\
\text { sabonete para fins cosméticos contendo óleo de } \\
\text { semente de macaúba (acronomiaacumleata) }\end{array}$ & PI 1005633 & Brasil - 18/11/2014 \\
\hline $\begin{array}{l}\text { Processo de fabricação de } \text { produto } \\
\text { tratamento da psoríase }\end{array}$ & 102012022291 & Brasil - 21/01/2015 \\
\hline $\begin{array}{l}\text { Transdermal delivery of anastrozole for systemic } \\
\text { effect }\end{array}$ & 20150065545 & $\begin{array}{l}\text { EstadosUnidos } \\
05 / 03 / 2015\end{array}$ \\
\hline $\begin{array}{l}\text { Composição farmacêutica de nanopartículas de } \\
\text { prata em óleo de copaíba para preparação de } \\
\text { medicamento cicratizante e/ou bactericida }\end{array}$ & 102013005468 & Brasil - 02/06/2015 \\
\hline $\begin{array}{l}\text { Composição orgânica indicada para a } \\
\text { terapêutica de processos } \\
\text { inflamatórios e antineoplásticos }\end{array}$ & PI 1102276 & Brasil - 04/08/2015 \\
\hline $\begin{array}{l}\text { Nanoemulsão aquosa, uso de nanoemulsão } \\
\text { aquosa e processo de nanoemulsão aquosa }\end{array}$ & 102013030303 & Brasil - 20/10/2015 \\
\hline $\begin{array}{l}\text { Inseticida natural à base de ácido graxos de } \\
\text { coco babaçu com efeito de inceticida; fungicida; } \\
\text { bactericida e virocida }\end{array}$ & 102013013334 & Brasil - 10/11/2015 \\
\hline
\end{tabular}

*Patentes em domínio público

\begin{tabular}{|l|l|l|}
\hline TABELA 2 - ÓLEO SUBSTITUÍVEL & $\begin{array}{l}\text { NÚMERO DE } \\
\text { REGISTRO }\end{array}$ & $\begin{array}{l}\text { PAÍS DE ORIGEM E } \\
\text { DATA }\end{array}$ \\
\hline $\begin{array}{l}\text { Loção para tratamento capilar e respectivo } \\
\text { processo de preparação }\end{array}$ & PI 9903518 & Brasil - 24/04/2001 \\
\hline Composição removedora de esmalte para unhas & PI 0301845 & Brasil - 03/11/2004 \\
\hline $\begin{array}{l}\text { Composto polimérico aquoso de látex vegetal } \\
\text { associado a fibras vegetais e processo de } \\
\text { obtenção }\end{array}$ & PI 0405902 & Brasil - 22/08/2006 \\
\hline
\end{tabular}




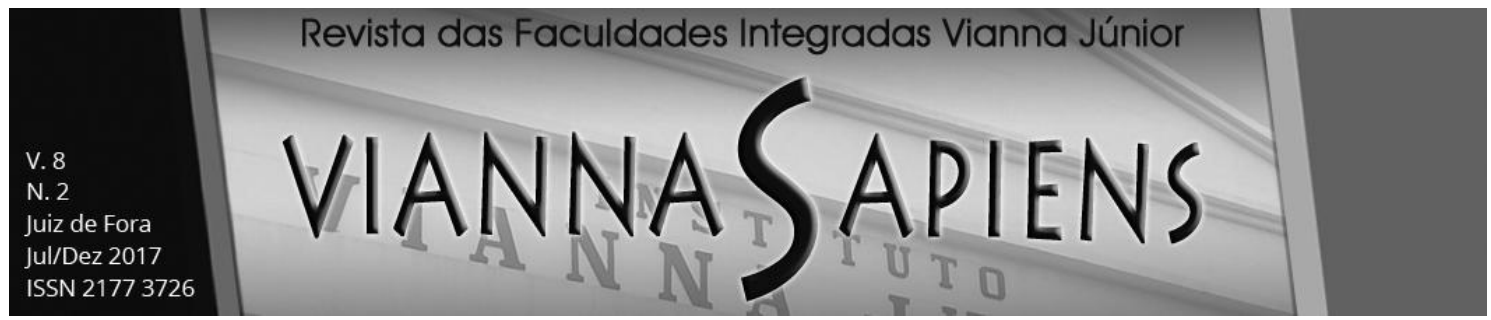

Composições farmacêuticas e/ou cosméticas e/ou terapias celulares utilizando culturas de diversos tipos de células, compostas pela utilização da vitamina (e/ou pelos derivados da vitamina $\mathrm{C}$ em adição e/ou em combinações associativas entre si e/ou com outras substâncias, especialmente e não somente a vitamina $\mathrm{E}$ e/ou derivados da vitamina $\mathrm{E}$

Composição anídrica fornecedora de sabor e processo

Produto de material de construção

Solubilizing composition and use thereof in methods relating to alkaline solubilization of samples

"Compositiónsolubilizante de muestras inorgánicas y orgânicas, de origen animal, vegetal y humano"

Method for obtaining high concentrations of the chemical constituent trans-pinocarvyl acetate by hidrodistillation of the aerial parts of microliciagraveolens and obtaining manoemulsified formulations

Processo de obtenção em altas concentrações do constituinte químico acetato de transpinocarvila por hidrodestilação das partes aéreas de microliciagraveolens e obtenção de formulações nanomulsionadas Composições bioativas de plantas a base de óleos essenciais, na forma de gel, para banho seco, adequado para aplicação tópica na pele e de animais

\begin{tabular}{|l|l|}
\hline PI 0505703 & Brasil - 18/09/2007 \\
\hline PI 0707389 & Brasil - 21/03/2011 \\
\hline PI 1001720 & Brasil - 18/05/2011 \\
\hline WO/2012/045138 & Brasil-12/04/2012 \\
\hline 0001033649 & Brasil - 30/04/2012 \\
\hline W0/2014/000077 & Brasil-03/01/2014 \\
\hline 102012015756 & Brasil - 02/12/2014 \\
\hline 102013015841 & Brasil - 30/06/2015 \\
\hline
\end{tabular}

\begin{tabular}{|l|l|l|}
\hline $\begin{array}{l}\text { TABELA 3 - PATENTES QUE } \\
\text { MISTURAM PRODUTOS NATURAIS }\end{array}$ & $\begin{array}{l}\text { NÚMERO DE } \\
\text { REGISTRO }\end{array}$ & $\begin{array}{l}\text { PAÍS DE ORIGEM E } \\
\text { DATA }\end{array}$ \\
\hline Composição natural para a cura do câncer & PI 9705573 & Brasil-06/07/1999 \\
\hline $\begin{array}{l}\text { Loção para tratamento capilar e respectivo } \\
\text { processo de preparação }\end{array}$ & PI 9903518 & Brasil-24/04/2001 \\
\hline $\begin{array}{l}\text { Composto polimérico aquoso de látex vegetal } \\
\text { associado a fibras vegetais e processo de } \\
\text { obtenção pI 0405902 }\end{array}$ & Brasil-22/08/2006 \\
\hline $\begin{array}{l}\text { Processo para preparação de composição } \\
\text { cosmética com propriedades farmacêuticas de } \\
\text { elevada absorção; método para prevenção e/ou } \\
\text { tratamento de inflamações da pele de mamíferos, } \\
\text { utilizando composição cosmética com } \\
\text { propriedades farmacêuticas de elevada absorção, } \\
\text { método para regenerar tecido cutâneo submetido } \\
\text { à radioterapia, utilizando composição cosmética } \\
\text { com propriedades farmacêuticas de elevada } \\
\text { absorção }\end{array}$ & & \\
\hline
\end{tabular}




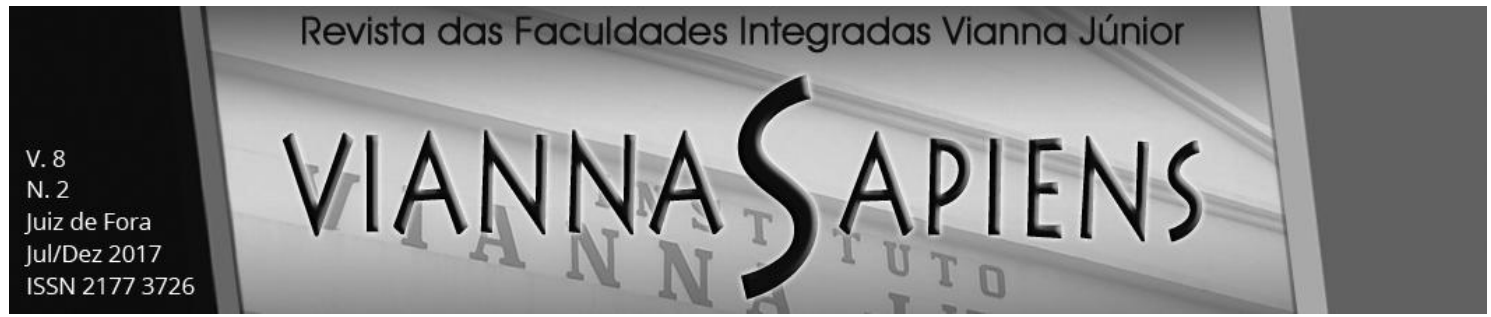

\begin{tabular}{|l|l|l|}
\hline Máscara rejuvenescedora de argila em pó & PI 0603411 & Brasil - 26/12/2007 \\
\hline $\begin{array}{l}\text { Composição natural e processo de tratamento de } \\
\text { insumos para confecção de artesanato usando } \\
\text { dita composição }\end{array}$ & PI 0700960 & Brasil - 09/09/2008 \\
\hline $\begin{array}{l}\text { "Compositiónsolubilizante de muestras } \\
\text { inorgánicas y orgânicas, de origen animal, } \\
\text { vegetal y humano" }\end{array}$ & 0001033649 & Brasil-30/04/2012 \\
\hline
\end{tabular}

A partir destes dados e, retomando o processo metodológico inferencial descrito, passa-se à realização das inferências (EPSTEIN; KING, 2013), a saber: a ausência da novidade como requisito para o patenteamento e 0 processo de biopirataria da copaíba como inferências causais e, como inferência descritiva, a bioprospecção como uma forma disfarçada de biopirataria.

Algumas críticas se destacam diante destas patentes, a começar pelo fato de que é claramente visível o tradicional como algo apropriado por terceiros, sem o mínimo de inovação que justifique sua concessão. Malgrado se encontre a possibilidade de patentear o conhecimento tradicional de modo disfarçado, sequer há nestas patentes a presença do pressuposto de novidade em suas descrições. A concessão do registro apenas por cumprir os requisitos legais remete a uma posição confortável e que evita conflitos, sem o mínimo de questionamento, mas esta posição que evita complexidades é exatamente a mesma que conduz ao fracasso (BANKOWSKI, 2007).

Aplicar a legislação de forma mecânica, sem avaliar critérios basilares para que essas patentes viessem a existir, serve para reafirmar a proposta de Zenon Bankowski (2007) sobre a necessidade e o momento adequado de romper com a legislação vigente e enxergar o próximo como sujeito de direitos e deveres, que compartilha de um mesmo espaço, ainda que possua escolhas diferentes. Viver o direito plenamente não significa optar por um extremo que proporcionará a redução de conflitos, até mesmo porque estes são degraus de superação e avanço. Uma vida plena consiste em compreender quais são as aspirações existentes em cada regra instituída, considerando que sempre 


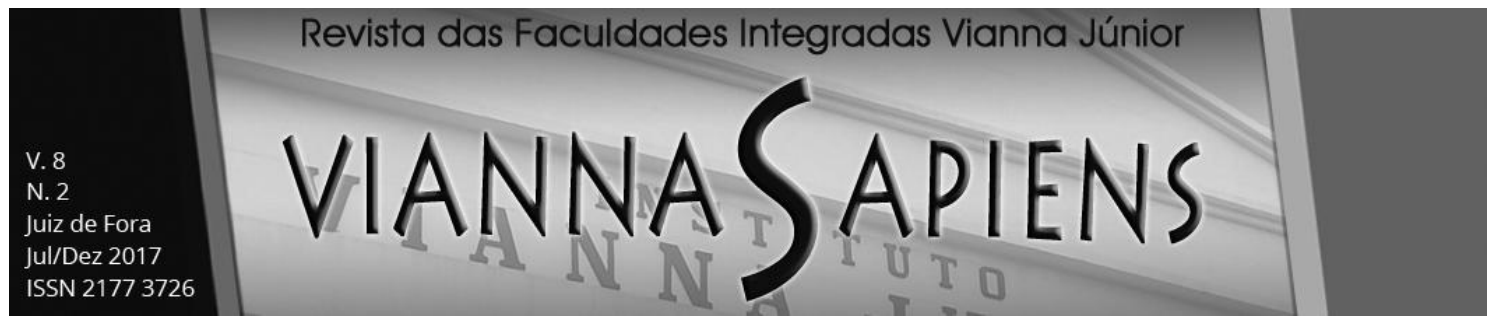

haverá a possibilidade de sua reformulação e é neste momento que o legalismo se diferencia da legalidade, uma vez que as normas devem ser modificadas para que ocorra um benefício maior de aspirações. Logo, a plenitude só é alcançada pela convivência entre lei e amor, ainda que eles venham a colidir ao decorrer do tempo.

Observando a utilização da copaíba (tanto a madeira quanto seu óleo) e as propriedades medicinais que diversas comunidades tradicionais, nas cinco regiões do país, descobriram ao longo dos anos é possível notar que algumas patentes apresentam exatamente o que estes povos dominam. Como exemplo tem-se o caso das patentes compostas por produtos naturais para a cura do câncer, casos em que a copaíba se integra como conteúdo necessário para a cura de doenças pulmonares e patentes que possuem em seu produto efeito cicatrizante, considerando que comunidades tradicionais a utilizam para cura e tratamento dessas enfermidades por longínquos tempos.

Diante das tabelas apresentadas é preciso observar que alguns requisitos para o processo de patenteamento foram negligenciados, permitindo, inclusive, questionar a atuação de órgãos responsáveis por conceder as patentes, somado aos dispositivos legais, haja vista que estes se apresentam disfarçados de ordens normativas cujo sentido de existir é exatamente a proteção daqueles que não possuem capacidade de defesa perante outrem, ou seja, o ingênuo.

Contudo, em seu contexto de aplicação, tais ordens normativas acabam por favorecer o interesse econômico dos demais, permitindo-o preponderar sobre o conhecimento tradicional associado, haja vista que, ao voltar-se para as funções que a copaíba exerce em povos tradicionais, principalmente sua utilização por nordestinos e indígenas e, ao olhar para as tabelas apresentadas, é possível visualizar diversas patentes cuja finalidade de seus produtos condiz exatamente com sua utilização por estes povos.

Constata-se que a própria legislação anteriormente mencionada apresenta requisitos indispensáveis para a obtenção de patentes, 


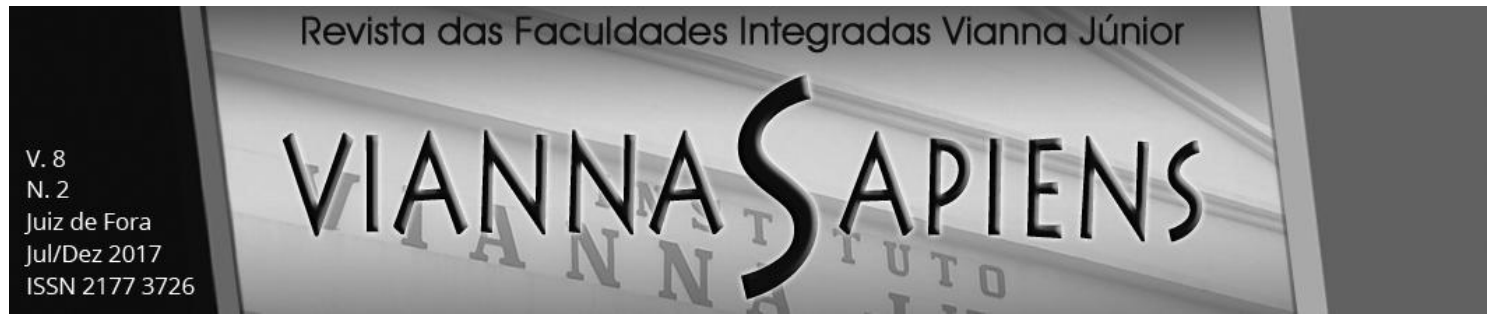

demonstrando o rol taxativo de substâncias que não podem ser patenteadas, mas ao mesmo tempo deixa de atuar, sendo omissa no que tange ao conhecimento tradicional, embora destaque a importância do compartilhamento de benefícios de forma justa e equitativa.

Logo, é possível confirmar que a denominada bioprospecção consiste em uma forma velada de biopirataria, sendo seu objetivo a análise da biodiversidade, a retirada de componentes que geram interesse e sua utilização, seja de recursos genéticos ou bioquímicos, desde que sejam rentáveis.

A bioprospecção é, portanto, incompatível com a escolha de vida de comunidades tradicionais, uma vez que estas estão em contato com o que julgam de crucial importância ou valor fundamental. Grupos sociais se diferem exaustivamente no que tange à sua cultura e aos seus valores. $O$ fato de determinados bens existirem, como é o caso do conhecimento tradicional, conduz ao reconhecimento de que certos bens somente existem quando lhe asseguram a existência de pessoas dentro de sua específica forma cultural (TAYLOR, 1997).

A permanência dessas pessoas com seus costumes e conhecimentos não é algo para exploração, mas serve como a aspiração que os proporcionará uma vida plena. Assim é a escolha do viver tradicional, embora ocorra ao seu redor um bombardeamento de crenças que afirmam deter uma cultura relativamente melhor, esquecendo-se de que suas práticas podem ser errôneas, etnocêntricas e até mesmo insensíveis.

\section{CONCLUSÃO}

Após percorrer o caminho traçado com os referenciais teóricos, a metodologia aplicada, uma breve noção acerca da megadiversidade brasileira, as normas que regem a proteção à biodiversidade e o caso empírico, é 


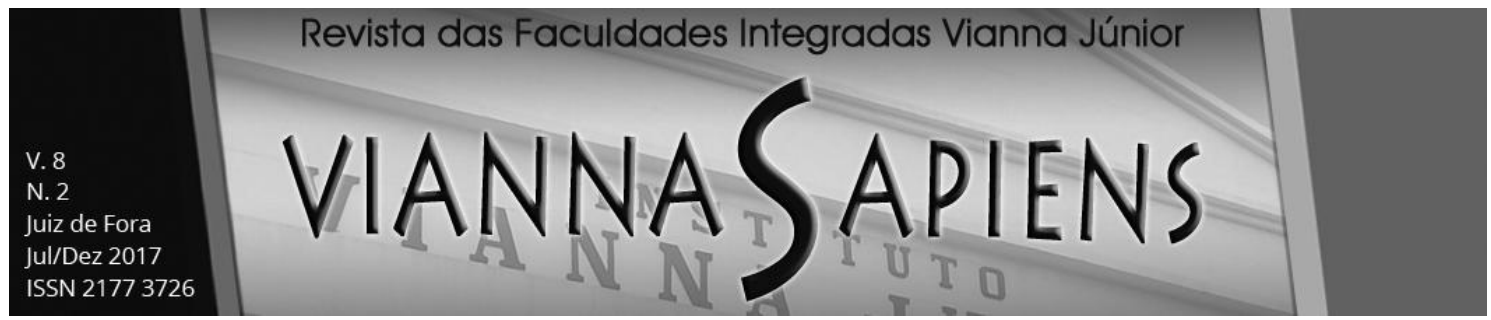

possível afirmar que o tradicional, rico por si mesmo, autônomo e firmado em suas escolhas delineadas por seus povos não são os verdadeiros amparados pelas normas. Não há que se alegar sobre serem os tradicionais ingênuos, indefesos, mas há a necessidade de reconhecê-los como sujeitos de direito que escolheram a forma de vida que mais lhe compraz.

As patentes que apresentam a copaíba como seu composto não demonstram legitimidade, pois refletem exatamente a exploração do tradicional, uma vez que, como visualizado nas tabelas, atestam como sua propriedade o saber que povos tradicionais possuem por anos. Ademais, não se verifica também sua legalidade, pois não há a certificação de novidade e, em algumas vezes, há o patenteamento de descobertas. Portanto, é mister combater a denominada "bioprospecção" para que ocorra a preservação da megadiversidade e para evitar que mais patentes surjam com os mesmos propósitos de exploração.

Verificando o patenteamento da copaíba, é preciso questionar a falta de especificidade das normas, uma vez que as patentes registradas seguiram os passos estabelecidos pelos órgãos responsáveis, mas ainda assim houve lacunas que propiciaram a preponderância do interesse econômico diante do tradicional, vindo inclusive disfarçado através do argumento da distribuição equitativa de benefícios.

Há que se repensar o TRIPS à luz dos dispositivos da CBD, especificamente ao relatar sobre o respeito ao estilo de vida escolhido por comunidades tradicionais. Alegar a existência da prática de bioprospecção é manter um véu que dá cobertura à biopirataria, facilitando para que descobertas e mistura de elementos naturais para tratamentos de determinadas enfermidades, benefícios estéticos, dentre outros, que são trabalhados e desenvolvidos em diversas culturas no decorrer dos anos sejam patenteados.

A meta desejável é denunciar a ocorrência de tais práticas que ocorrem de modo velado, um sistema colonizador, assim como foi no Brasil desde as 


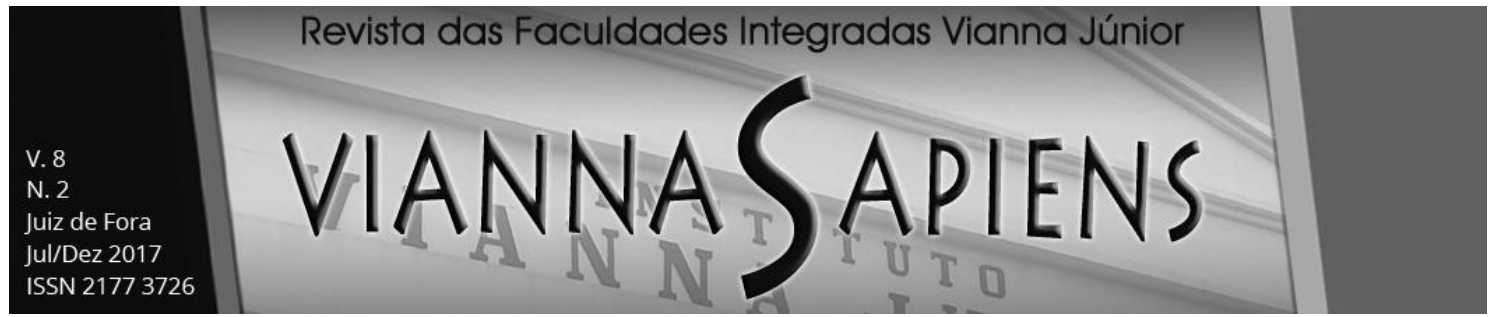

primeiras embarcações oriundas de Portugal, cujos argumentos se disfarçavam de ensinamento e catequismo para aqueles que simplesmente eram donos de um espaço livre, com suas práticas de liberdade e crenças em seus hiperbens. É preciso reconhecer que o próximo não é um objeto ou um meio para que interesses particulares sejam alcançados, mas é alguém que compartilha de um mesmo espaço.

As sociedades humanas são compostas por diferenças culturais e valorativas e isto representa formas diferentes de se ser humano. Portanto, é preciso desenvolver não somente uma consciência moral, mas também justa, haja vista que mesmo em conflitos pela relação de lei e amor, estruturá-los de forma coerente é o que proporcionará o devido respeito ao tradicional.

\title{
PATENT REGISTRATION AND TRADITIONAL KNOWLEDGE: biodiversity protection?
}

\begin{abstract}
The aim of this paper is to investigate the traditional knowledge of community, as well as the legislation aiming their protection facing the immeasurable economic interest surrounding it. It takes an analysis regarding the legality and legitimacy of patents originated by biodiversity components and the discussion of its protection, stressing the capability and potential of traditional people, whose knowledge comes from contact and experience with nature itself. In order to develop arguments critically, the analysis regards in the ZenonBankowski's living lawfully and the Charles Taylor's structuring of modern identity, when discussing the sources of the self. Moreover, we will study factors previously established in international treatises, such as TRIPS and CBD,
\end{abstract}




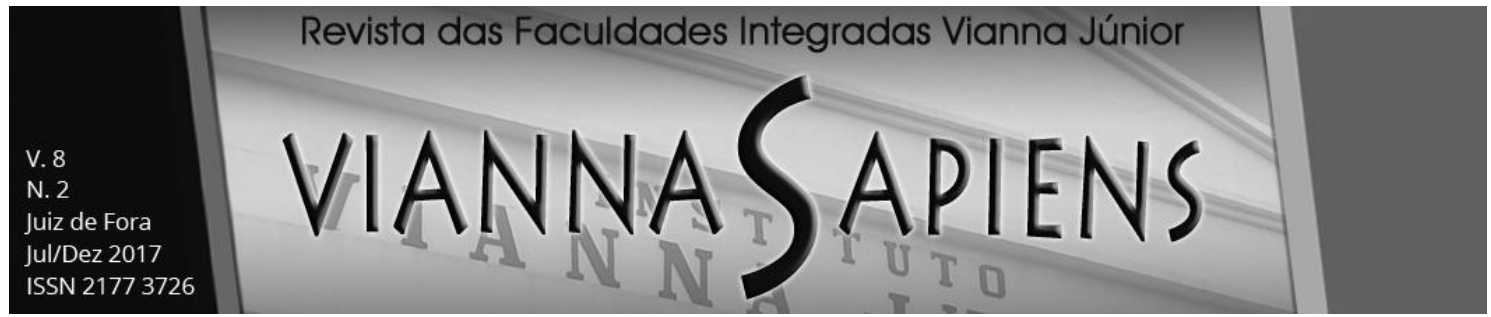

presenting a study about copaiba that will highlight the need of reconstructing vision about traditional communities, through drawn methodological lines.

KEYWORDS: BIODIVERSITY. LEGALITY. PATENTS. TRADITIONAL KNOWLEDGE.

\section{REFERÊNCIAS}

BANKOWSKI, Zenon. Vivendo plenamente a lei. Rio de Janeiro. Elsevier, 2007. 328p.

$\overline{1, \text { p.25-42, } 1996 .}$

Law, Love andComputers. Edinburgh L. Ver., Edimburgo, v.

BARROS, M. A. G. Flora medicinal do Distrito Federal. Brasil Florestal, Brasília, v. 12, n. 50, p.35-45, 1982.

BÍBLIA. Lucas. Bíblia de Estudo Almeida, Barueri. Sociedade Bíblica do Brasil, 2006, 1728p.

BRANDÃO, M. Plantas e medicamentos do cerrado brasileiro. Informe Agropecuário, Belo Horizonte, v. 15, p.15-20, 1991.

CORREA, M. P. Dicionário das plantas úteis do Brasil e das exóticas cultivadas. Rio de Janeiro: IBDF, v. 6, 1978.

CUNHA, Manuela Carneiro da. Introdução a uma história indígena. In

História dos índios no Brasil. 2.ed. São Paulo, Companhia das Letras, 2006.

CALIXTO, João B. Biodiversidade como fonte de medicamentos. Cienc. Cult., São Paulo, v.55, n.3, Sept. 2003. 


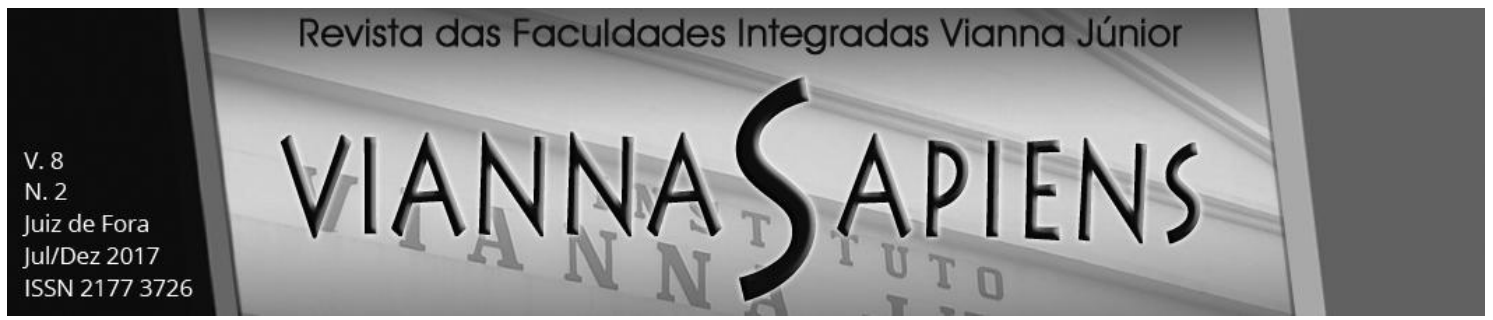

CARVALHO, Paulo Ernani Ramalho. Espécies Arbóreas Brasileiras. Brasília: Embrapa Informação Tecnológica. Embrapa Florestas, 2003.

EPSTEIN, Lee; KING, Gary. As regras de inferência. São Paulo: Direito GV, 2013.

ITOMAN, M. K.; SIQUEIRA, A. C. M. DE F.; CAVASSAN, O. Descrição de quinze espécies arbóreas de mata mesófila do Estado de São Paulo ameaçadas de extinção. Salusvita. Bauru, v. 11, n. 1. p. 1-38, 1992.

LORENZI, H.; MATOS, F. J. A. Plantas medicinais do Brasil: nativas e exóticas. 2. ed. Nova Odessa: Instituto Plantarum, 2008.

Organização Mundial de Propriedade Intelectual. PatentScope. Database, 2015. Disponível em: <http://patentscope.wipo.int/search/en/result.jsf> Acesso em: 20 jul. 2017.

PAULA, J. E. de. Estudo das estruturas internas das madeiras de dezesseis espécies da flora brasileira, visando seu aproveitamento para produção de álcool, carvão, coque e papel. Brasil Florestal, Brasília, v. 11, n. 47, p. 23-50, 1981.

TAYLOR, Charles. As fontes do self. A construção da identidade moderna. São Paulo: Loyola, 1997.

TESKE, M. TRENTINI, A. M. M. Herbarium: compêndio de fitoterapia. 3. ed. Curitiba: Ingra, 1997. 317p.

SACCARO JUNIOR, Nilo L. A regulamentação de acesso a recursos genéticos e repartição de benefícios: disputas dentro e fora do Brasil. Instituto de Pesquisa Econômica Aplicada: Brasília, 2011.

SENE, Eustáquio de. MOREIRA, João Carlos. Espaço geográfico e globalização. 2 ed. São Paulo: Scipione, 2013. 


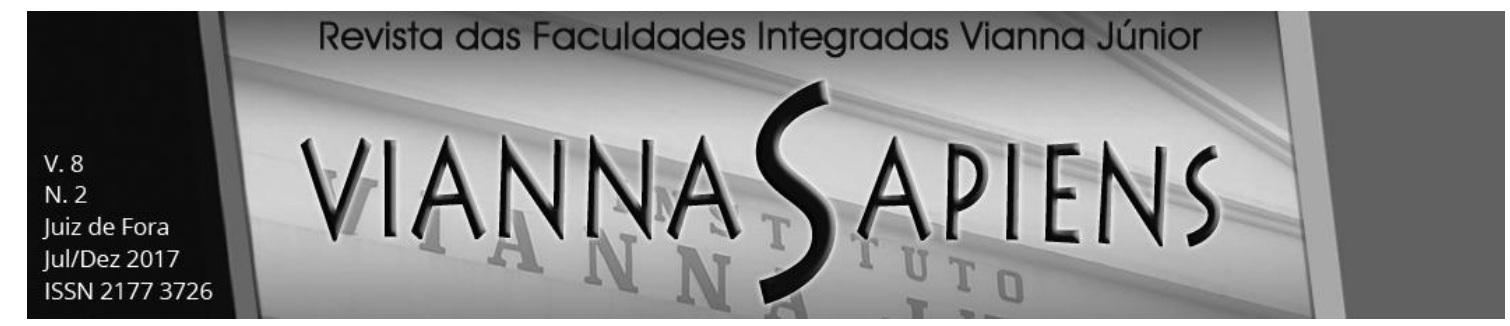

SILVA, J. A. da.Conservação genética "in situ" de populações de espécies arbóreas. Silvicultura, São Paulo, n. 41, p. 85-89, 1986. Edição do 5응 Congresso Florestal Brasileiro, Olinda, PE, Nov. 1986.

SIQUEIRA, A. C. M. F.; NOGUEIRA, J. C. B. Essências brasileiras e sua conservação genética no Instituto Florestal de São Paulo. Revista do Instituto Florestal, São Paulo, v. 4, PT. 4, p. 1187, 1992.

UNU-IAS. United NationsUniversity - Institute of Advanced Studies: report. BioprospectingofGeneticResources in theDeepSeabed: Scientific, Legal andPolicyAspects, 2005.

VEIGA JUNIOR, V.F.; PINTO, A.C. O Gênero copaifera L. Química nova, v.25, n.2, p.273-86, 2002. 